\title{
Brown algae (Phaeophyta) for monitoring heavy metals at the Sudanese Red Sea coast
}

\author{
Abuagla Y. A. Ali ${ }^{1}$ Abubakr M. Idris ${ }^{2}$ Ammar M. Ebrahim ${ }^{3,4}$. \\ Mohmaed A. H. Eltayeb ${ }^{3}$
}

Received: 6 June 2016/ Accepted: 11 January 2017/Published online: 10 February 2017

(c) The Author(s) 2017. This article is published with open access at Springerlink.com

\begin{abstract}
This study aimed at monitoring some heavy metals at the Sudanese Red Sea coast using Brown algae (Phaeophyta) as biomonitor. The total contents of heavy metals in four species (Turbinaria sp., Sargassum sp., Cystoseira sp. and Padina sp.) as well as seawater were examined. Twenty-six algae samples were collected from seven locations. The ranges of concentrations $(\mu \mathrm{g} / \mathrm{g}$, dry wt.) of heavy metals in algae were $4.95-16.95$ for $\mathrm{Cr}$, 2.93-257.32 for $\mathrm{Mn}, 1.35-7.43$ for $\mathrm{Ni}, 0.83-14.10$ for $\mathrm{Cu}$, 4.13-19.13 for $\mathrm{Zn}, 0.03-0.15$ for $\mathrm{Cd}$ and $0.45-2.18$ for $\mathrm{Pb}$. The ranges of the $\mathrm{pH}$ and the salinity of seawater from the same locations were 8.11-8.82 and 38.00-41.00 PSU, respectively. The ranges of concentrations $(\mu \mathrm{g} / \mathrm{L})$ of heavy metals in seawater were $7.00-11.00$ for $\mathrm{Cr}, 2.90-10.20$ for $\mathrm{Mn}, 6.70-10.10$ for $\mathrm{Ni}, 1.70-5.00$ for $\mathrm{Cu}, 0.94-5.70$ for $\mathrm{Zn}$, $0.09-0.14$ for $\mathrm{Cd}$ and $0.93-1.80$ for $\mathrm{Pb}$. No significant correlations between metal concentrations in algae and seawater were observed. Some locations in the study area recorded relatively high levels of heavy metals in algae indicating possible contribution from manmade activities. $\mathrm{Cr}$ recorded higher levels in the study area than those in other coastal areas in the word. Padina sp. and Cystoseira sp. were better bioindicator than Turbinaria sp., Sargassum sp. for their high metal uptake.
\end{abstract}

Abubakr M. Idris

abubakridris@hotmail.com

1 Department of Chemistry, Faculty of Education, Red Sea University, Port-Sudan, Sudan

2 Department of Chemistry, College of Science, King Khalid University, Abha, Saudi Arabia

3 Sudan Atomic Energy Commission, Khartoum, Sudan

4 King Faisal University, Hofuf, Saudi Arabia
Keywords Biomonitoring · Heavy metals · Phaeophyta . Red Sea

\section{Introduction}

Monitoring of chemicals in the environment from both origins natural and anthropogenic requires efficient indicators. In marine environment, aquatic organisms are more efficient indicators than water and sediment because aquatic organisms demonstrate the bioavailable fraction of contaminants and hence reflect the direct risk (Phillips 1990; Chakraborty et al. 2014). Among other aquatic organisms, macroalgae have proven to be efficient in monitoring and sorption of metals because they act as sink for metals (Montazer-Rahmati et al. 2011; Lee and Park 2012). In addition, macroalgae can live in both systems clean and contaminated because they have the ability of adaptation to different environmental conditions (Rajfur et al. 2010). While green algae (Chlorophyta) are usually found in freshwater and terrestrial areas, red algae (Rhodophyta) and brown algae (Phaeophyta) are almost found in seawater (Hashim and Chu 2004).

Phaeophyta is a grand assemblage of macroscopic plants. More than 1500 Phaeophyta species have been identified (Davis et al. 2003). The brown color in Phaeophyta results from the large amounts of the carotenoid fucoxanthin, which masks other pigments (Hashim and Chu 2004). Phaeophyta has proven to be an effective bioindicator for metals due to the high density of carboxylic groups that present in alginate (the main component of their cell-wall). This feature results in high rate of metal accumulation (Phillips 2009; Hashim and Chu 2004; Försberg et al. 1988; Cazón et al. 2013). Electrostatic 
attraction and complexation take place in the cell-wall of Phaeophyta (Davis et al. 2003).

On the other hand, it is known that the coastal areas of the Red Sea are located in the arid zones. In addition, the Red Sea coastal areas suffer from the scarce of water sources that are fit for drinking and other purposes. Hence, the water of the Red Sea is the major source, after desalination treatment, for drinking, irrigation and industry in those areas. Accordingly, the monitoring of possible pollutants in the Red Sea water is of great of interest (Idris et al. 2007; Idris 2008).

The aims of this work were: (1) to determine the levels of $\mathrm{Cr}, \mathrm{Mn}, \mathrm{Ni}, \mathrm{Cu}, \mathrm{Zn}, \mathrm{Cd}$ and $\mathrm{Pb}$ in Phaeophyta and seawater samples collected from the Sudanese Red Sea coast, (2) to study the Phaeophyta species variability in metal uptake and (3) to assess the levels of metals in different sites in the study area and to compare those levels against other coastal areas in the world.

\section{Materials and methods}

\section{Study area}

This study was conducted at the Sudanese Red Sea coast (Fig. 1). The Red Sea is land-locked; a feature that restricts water exchange and hence enhance the enrichment of contaminants including heavy metals. Port-Sudan and Sawakin, which lie along the Sudanese Red Sea coast, are the main harbors of Sudan and South Sudan countries. Port-Sudan and Sawakin harbors witness dense shipping and recreational boating activities. Port-Sudan is a large city, with the area of $218,887 \mathrm{~km}^{2}$, and densely populated, with more than 520,000 residents. Port-Sudan also includes a wide industrial area with various processes. Swakin is a historical city in Sudan. It is more than 1000 years old.

\section{Sampling}

Twenty-six brown algae samples were collected during October and November, 2014. The samples were collected from the fringing reefs area with transect at c.50 m and depth in the range of $50-150 \mathrm{~cm}$. Four species including Turbinaria sp., Sargassum sp., Cystoseira sp. and Padina sp. were identified. Samples were stored in polyethylene bottles until transferring to laboratory. Samples were then flushed by seawater that was collected from the relevant locations. The soft parts in algae samples were separated and oven-dried at $105{ }^{\circ} \mathrm{C}$. Dried samples were crushed to fine powder for treatment.

Seawater samples were collected from the same locations of the algae sampled. Samples were collected from about $20 \mathrm{~cm}$ below the surface water to avoid floating matters. Samples were collected directly in polyethylene bottles. The bottles were previously cleaned with $10 \%(\mathrm{v} / \mathrm{v})$ nitric acid, double distilled deionized water and seawater. Seawater samples were then preserved for analysis by adding $0.5 \mathrm{~mL}$ of high purity nitric acid to each liter of a
Fig. 1 Map showing sampling stations along the Sudanese Red Sea coast

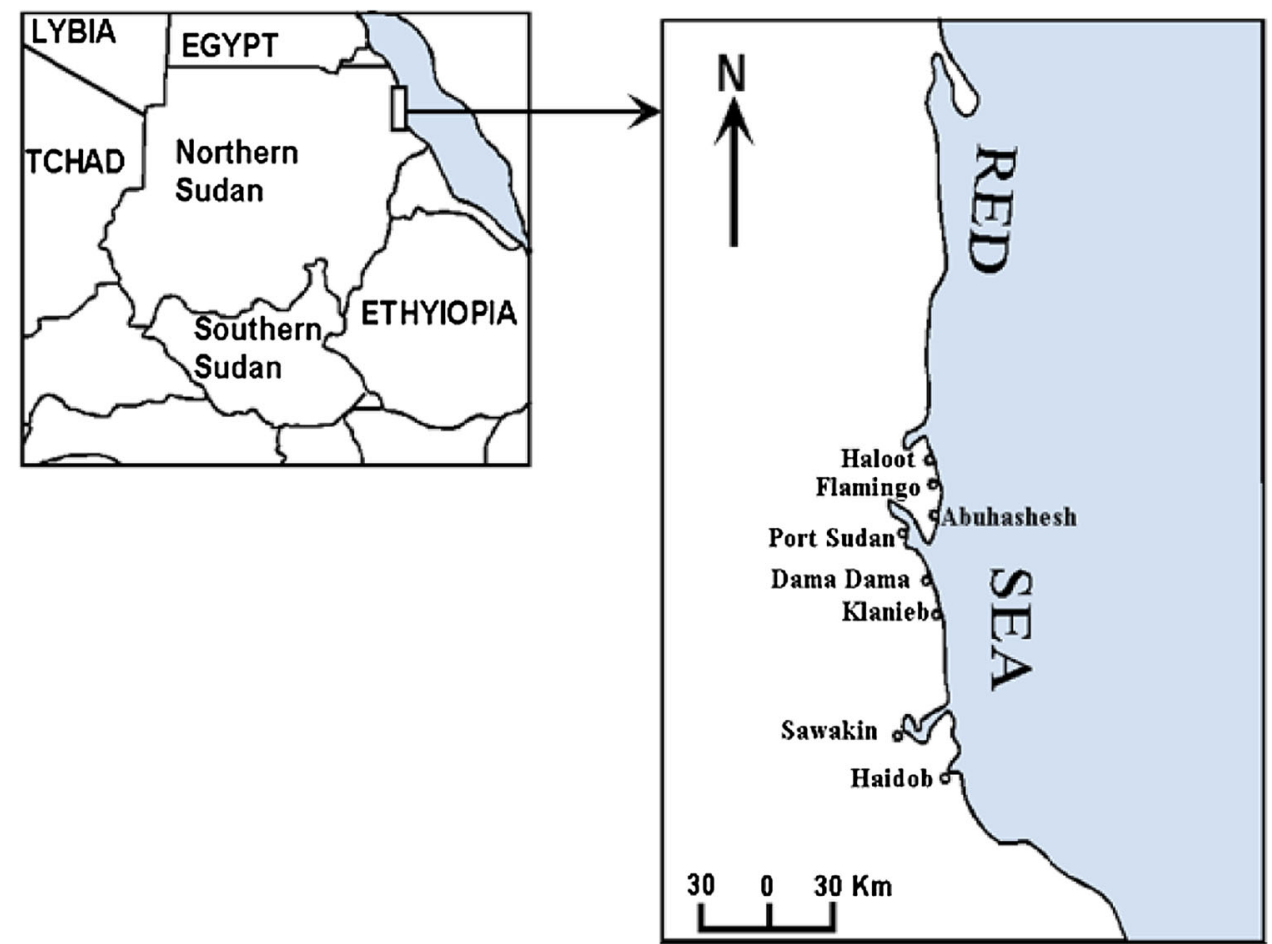


sample and stored at $25^{\circ} \mathrm{C}$. This acidification is believed to prevent the loss of metals by adsorption onto the walls of the polyethylene bottles.

\section{Treatment of algae samples}

Each alga sample was analyzed in triplicate. Wet digestion was applied for sample treatment. Seven $\mathrm{mL}$ of nitric acid were added to $1.0 \mathrm{~g}$ of dried homogenous powder sample in $100 \mathrm{~mL}$ beaker. The mixture was heated on a hotplate at $70{ }^{\circ} \mathrm{C}$ until dissolving and ceasing the evaporation of $\mathrm{NO}_{2}$. The solution was allowed to be at room temperature. Thereafter, $2 \mathrm{~mL}$ of perchloric acid were added and the mixture was heated again at $70{ }^{\circ} \mathrm{C}$ on a hotplate until evaporating the excess acid and the mixture became as paste. The mixture was diluted by double distilled deionized water in $50 \mathrm{~mL}$ volumetric flask. Sample solutions were then filtered to be ready for AAS measurement. Blank samples were prepared in triplicate and treated in parallel with algae samples using the same treatment procedure. A certified reference material (CRM) was also analyzed in parallel with algae samples. The CRM was IAEA-V-10, which has been certified by the International Atomic Energy Agency, Vienna, Austria.

\section{Measurements}

The $\mathrm{pH}$ of seawater was measured on-site. The concentrations of heavy metals were measured in algae and seawater by atomic absorption spectrometer (AAS). The system was SpectrAA 220, which was supplied from Varian (Palo Alto, CA. USA). Air/acetylene flame and deuterium background corrector were used. The system was equipped with sample introduction device. Hollow cathode lamps were used for metal excitations, which were performed at the following wavelengths and currents: $\mathrm{Cr}$ (357.9 $\mathrm{nm}$ and $12 \mathrm{~mA}), \mathrm{Mn}(279.5 \mathrm{~nm}$ and $15 \mathrm{~mA}), \mathrm{Ni}$ (232.0 $\mathrm{nm}$ and $40 \mathrm{~mA}), \mathrm{Cu}(324.7 \mathrm{~nm}$ and $25 \mathrm{~mA}), \mathrm{Zn}$ (213.9 $\mathrm{nm}$ and $15 \mathrm{~mA}), \mathrm{Cd}(228.8 \mathrm{~nm}$ and $20 \mathrm{~mA})$ and $\mathrm{Pb}$ (217 $\mathrm{nm}$ and $12 \mathrm{~mA}$ ). The instrument was calibrated using external mixed standard solutions, which were ready prepared by Sigma-Aldrich (Darmstadt, Germany). The AAS was calibrated for each metal using seven levels of concentrations.

\section{Results and discussion}

Table 1 shows the results of the quality control of the quantification of heavy metals. For CRM analysis, all measured values were within the confidence intervals. Acceptable recovery, with values in the range of $85-110 \%$, were obtained for all metals. For algae and seawater analysis, the average values of the concentrations of heavy metals, which were obtained from triplicate measurements, were considered. The values of the relative standard deviation (RSD) of the triplicate measurements were less than $7 \%$ indicating acceptable repeatability.

The summary statistics of the $\mathrm{pH}$ and the concentrations of salinity, $\mathrm{Cr}, \mathrm{Mn}, \mathrm{Ni}, \mathrm{Cu}, \mathrm{Zn}, \mathrm{Cd}$ and $\mathrm{Pb}$ in seawater are compiled in Table 2 . The summary statistics of metal concentrations in the algae samples are compiled in Table 3. Metal uptake by algae is influenced by some conditions such as the $\mathrm{pH}$ and the salinity of seawater, in addition to metal concentration in seawater (Morrison et al. 2008). The values of $\mathrm{pH}$ and salinity of seawater showed narrow ranges and small coefficients of variation $(<3 \%)$. The concentrations of heavy metals in seawater were in the following descending order: $\mathrm{Cr}>\mathrm{Ni}>\mathrm{Mn}>\mathrm{Cu}>$ $\mathrm{Zn}>\mathrm{Pb}>\mathrm{Cd}$. High coefficients of variation $(>50 \%)$ were recorded in the concentrations of $\mathrm{Mn}$ and $\mathrm{Zn}$ in seawater. However, the concentration ranges of $\mathrm{Mn}$ (2.90-10.20 $\mu \mathrm{g} / \mathrm{L})$ and $\mathrm{Zn}(0.94-5.70 \mu \mathrm{g} / \mathrm{L})$ were narrow. The levels of $\mathrm{pH}$ and salinity of seawater from the Sudanese Red Sea coast were comparable with those at two sites in the Irish coast (Morrison et al. 2008). Notably, the previous study considered one site was contaminated by heavy metals while the other site was considered free from contamination.

The average values of the concentrations of heavy metals in algae decreased in the following order: $\mathrm{Mn}>>\mathrm{Zn} \approx \mathrm{Cr}>\mathrm{Cu} \approx \mathrm{Ni}>\mathrm{Pb}>\mathrm{Cd}$. This order has found to be similar with that recorded in brown algae collected from the Amursky Bay, Russia (Khristoforova and Kozhenkova 2002) and the Black Sea, Bulgaria (Jordanova et al. 1999; Strezov and Nonova 2003). Similar order of algae uptake reflects the correspondence affinity of all brown algae species toward the levels of metal accumulation. It has been reported that significant amounts of divalent metals were accumulated by brown algae, which was attributed to the high levels of binding polysaccharides and polyphenols (Chakraborty et al. 2014; Hashim and Chu 2004).

In the current study, the average concentration of $\mathrm{Mn}$ in brown algae is almost ten-fold higher than $\mathrm{Zn}$ and $\mathrm{Cr}$ concentrations and 20-fold higher than $\mathrm{Cu}$ and $\mathrm{Ni}$ concentrations. Because of their natural origin, $\mathrm{Mn}$ and $\mathrm{Fe}$ presented the highest amounts in sediment from the Sudanese Red Sea coat. $\mathrm{Pb}$ and $\mathrm{Cd}$ recorded the minimum concentrations among other metals (Idris et al. 2007; Idris 2008). The concentrations of $\mathrm{Pb}$ and $\mathrm{Cd}$ in marine macroalgae have a special concern because of their manmade origin, non-point source and high toxicity (Strezov and Nonova 2003; Duan et al. 2014).

Figures 2, 3, 4, 5, 6, 7 and 8 show the concentrations of metals in each brown alga species from each location along 
Table 1 Results of quality control of heavy metals measurements by AAS

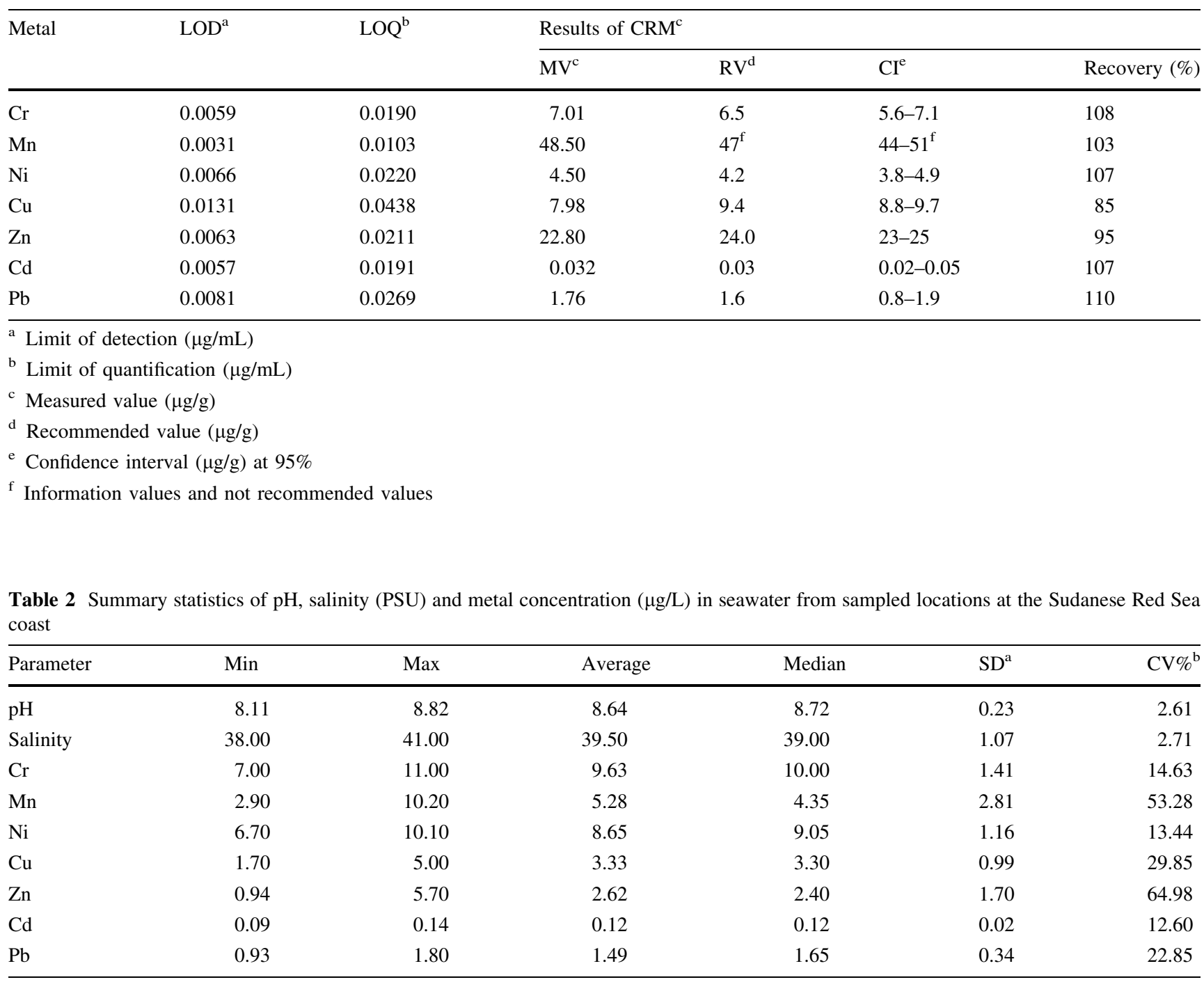

${ }^{a}$ Standard deviation

b Coefficient of variation

Table 3 Summary statistics $(n=26)$ of the concentrations ( $\mu \mathrm{g} / \mathrm{g}$, dry wt.) of some heavy metals in brown algae along the Sudanese Red sea coast

\begin{tabular}{|c|c|c|c|c|c|c|}
\hline Metal & Min & $\operatorname{Max}$ & Average & Median & $\mathrm{SD}^{\mathrm{a}}$ & $\mathrm{CV} \%^{\mathrm{b}}$ \\
\hline $\mathrm{Cr}$ & 4.95 & 16.95 & 9.55 & 9.00 & 2.39 & 25.03 \\
\hline $\mathrm{Mn}$ & 2.93 & 257.32 & 84.8 & 66.87 & 69.62 & 82.10 \\
\hline $\mathrm{Ni}$ & 1.35 & 7.43 & 4.82 & 4.58 & 1.47 & 30.50 \\
\hline $\mathrm{Cu}$ & 0.83 & 14.10 & 4.83 & 4.13 & 2.97 & 61.49 \\
\hline $\mathrm{Zn}$ & 4.13 & 19.13 & 10.97 & 8.89 & 4.75 & 43.30 \\
\hline $\mathrm{Cd}$ & 0.03 & 0.15 & 0.07 & 0.08 & 0.03 & 42.86 \\
\hline $\mathrm{Pb}$ & 0.45 & 2.18 & 1.28 & 1.32 & 0.44 & 34.38 \\
\hline
\end{tabular}

${ }^{a}$ Standard deviation

b Coefficient of variation 


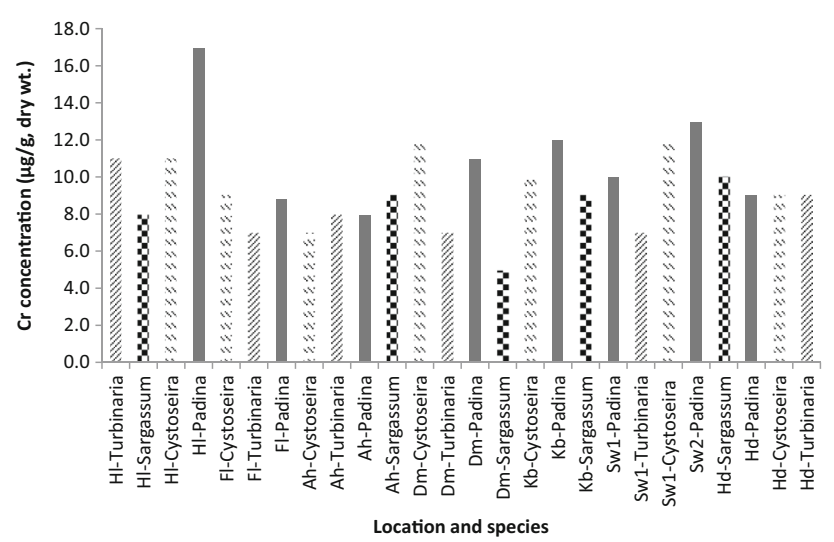

Fig. $2 \mathrm{Cr}$ concentration in brown algae species collected from locations at the Sudanese Red Sea coast; the full names of locations are $\mathrm{Hl}$ Haloot, $\mathrm{Fl}$ Flamingo, $\mathrm{Ah}$ Abuhashish, $\mathrm{Dm}$ Dama-Dama, $\mathrm{Kb}$ Klaineb, $S w$ Sawakin and $H d$ Haidoob

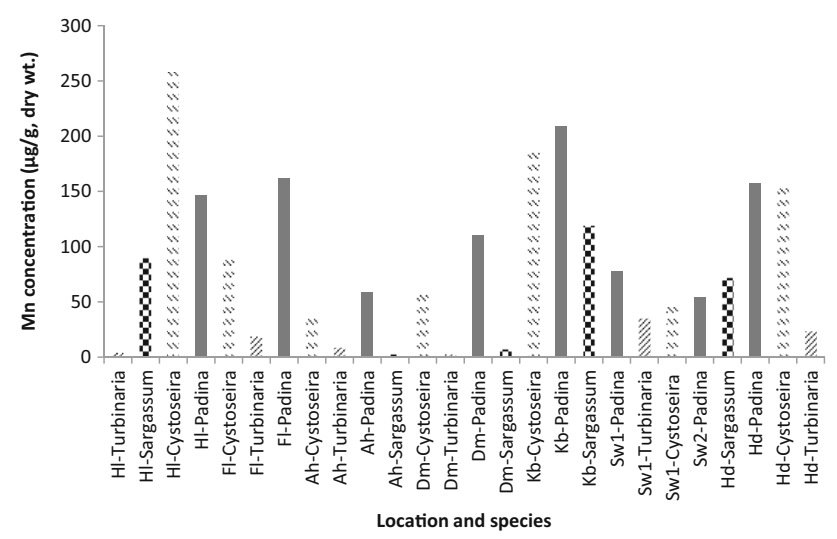

Fig. $3 \mathrm{Mn}$ concentration in brown algae species collected from locations at the Sudanese Red Sea coast; the full names of locations are $\mathrm{Hl}$ Haloot, $\mathrm{Fl}$ Flamingo, $\mathrm{A} h$ Abuhashish, $\mathrm{Dm}$ Dama-Dama, $\mathrm{Kb}$ Klaineb, $S w$ Sawakin and $H d$ Haidoob

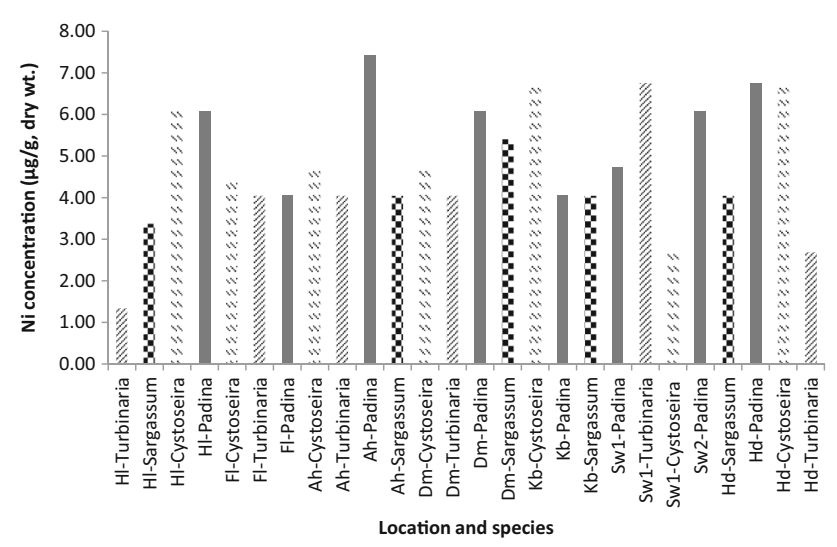

Fig. $4 \mathrm{Ni}$ concentration in brown algae species collected from locations at the Sudanese Red Sea coast; the full names of locations are $\mathrm{Hl}$ Haloot, $\mathrm{Fl}$ Flamingo, $\mathrm{Ah}$ Abuhashish, $\mathrm{Dm}$ Dama-Dama, $\mathrm{Kb}$ Klaineb, $S w$ Sawakin and $H d$ Haidoob

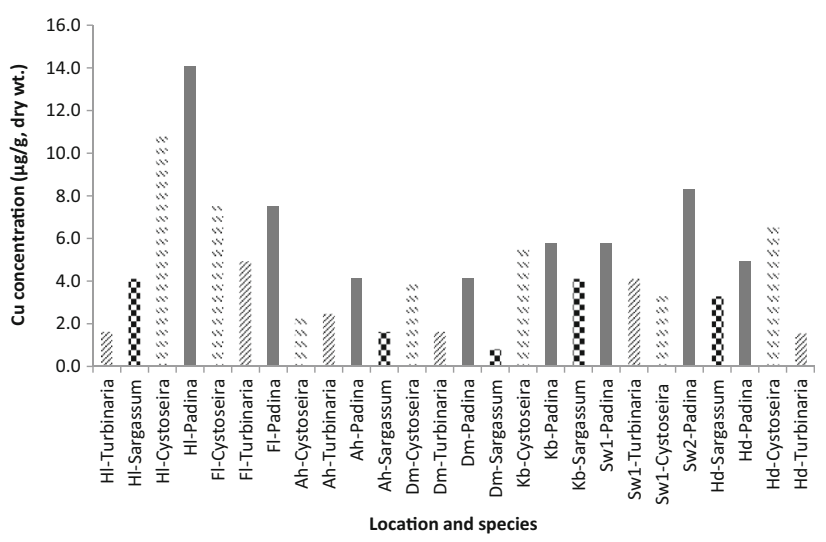

Fig. $5 \mathrm{Cu}$ concentration in brown algae species collected from locations at the Sudanese Red Sea coast; the full names of locations are $\mathrm{Hl}$ Haloot, $\mathrm{Fl}$ Flamingo, $\mathrm{Ah}$ Abuhashish, $\mathrm{Dm}$ Dama-Dama, $\mathrm{Kb}$ Klaineb, $S w$ Sawakin and $H d$ Haidoob

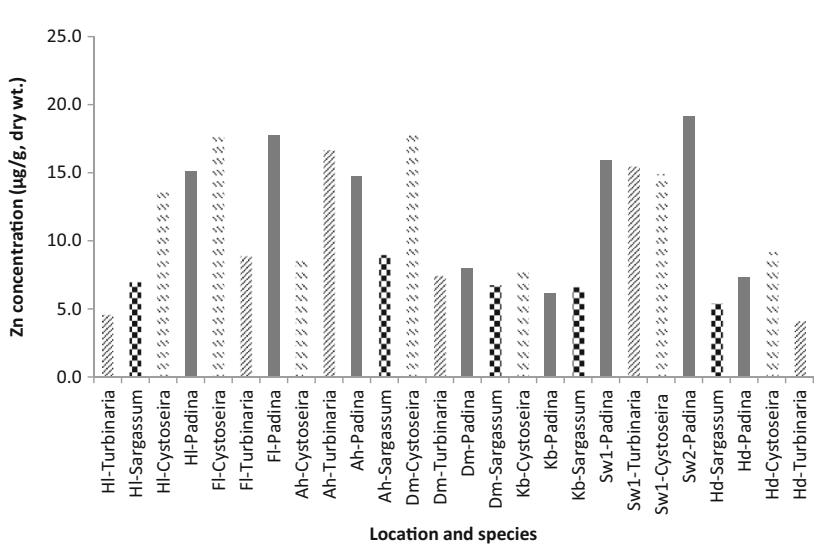

Fig. $6 \mathrm{Zn}$ concentration in brown algae species collected from locations at the Sudanese Red Sea coast; the full names of locations are $\mathrm{Hl}$ Haloot, $\mathrm{Fl}$ Flamingo, $\mathrm{Ah}$ Abuhashish, $\mathrm{Dm}$ Dama-Dama, $\mathrm{Kb}$ Klaineb, $S w$ Sawakin and $H d$ Haidoob

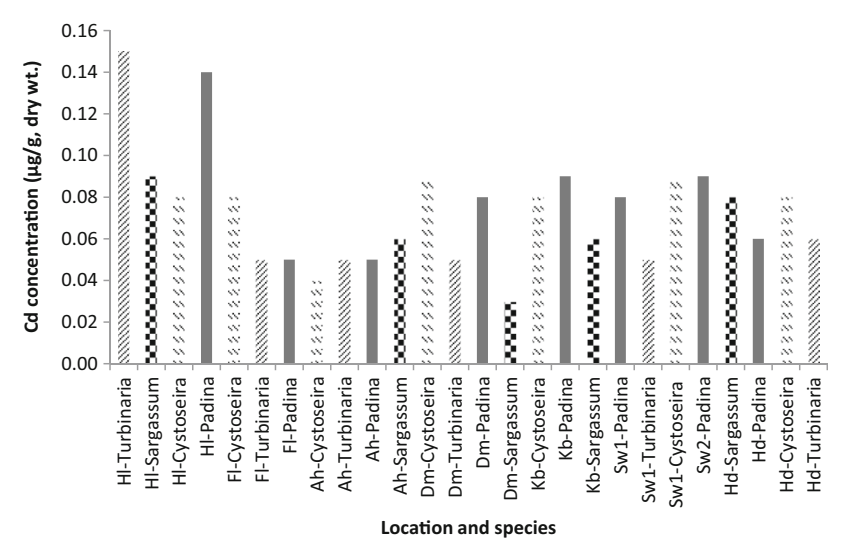

Fig. $7 \mathrm{Cd}$ concentration in brown algae species collected from locations at the Sudanese Red Sea coast; the full names of locations are $\mathrm{Hl}$ Haloot, $\mathrm{Fl}$ Flamingo, $\mathrm{Ah}$ Abuhashish, $\mathrm{Dm}$ Dama-Dama, $\mathrm{Kb}$ Klaineb, $S w$ Sawakin and $H d$ Haidoob

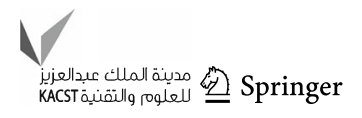




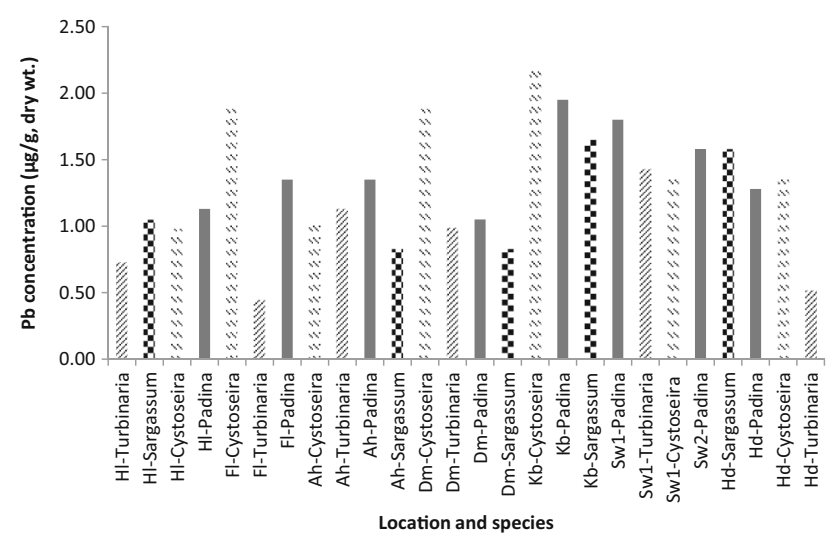

Fig. $8 \mathrm{~Pb}$ concentration in brown algae species collected from locations at the Sudanese Red Sea coast; the full names of locations are $\mathrm{Hl}$ Haloot, $\mathrm{Fl}$ Flamingo, $\mathrm{A} h$ Abuhashish, $\mathrm{Dm}$ Dama-Dama, $\mathrm{Kb}$ Klaineb, $S w$ Sawakin and $H d$ Haidoob

the Sudanese Red Sea coast. In general, different metal concentrations were observed in different species from one location. This issue confirms the variation in species affinity toward metal uptake. As shown in Fig. 2, Padina sp. and Cystoseira sp. recorded higher $\mathrm{Cr}$ uptake than Turbinaria sp. and Sargassum sp. Irrespective of algae species, the highest $\mathrm{Cr}$ uptake was observed at Haloot location, which may indicate $\mathrm{Cr}$ contribution from anthropogenic sources. Padina sp. and Cystoseira sp. also recorded higher Mn uptake than other species (Fig. 3). High uptake of Mn by Cystoseira sp. was observed at Haloot, Klaineb and Haidob locations. This issue could also indicate possible Mn contribution from anthropogenic sources. For $\mathrm{Ni}$ (Fig. 4), the highest uptake was also observed by Padina sp. and Cystoseira sp. However, no location recorded significant elevated levels of $\mathrm{Ni}$. In Fig. 5, Padina sp. and Cystoseira sp. from Haloot locations recorded the highest $\mathrm{Cu}$ uptake. On the other hand, Haloot, Flamingo, Abuhashish and Sawakin locations may be enriched by $\mathrm{Zn}$ from man-made activities, a finding that could be observed by high uptake by Padina sp. and Cystoseira sp. (Fig. 6). Cd (Fig. 7) significantly accumulated in Turbinaria sp., Sargasum sp. and Padina sp. from Haloot location. For Pb (Fig. 8), Cystoseira sp. recorded the highest uptake at all locations. On the other hand, no significant elevated levels of $\mathrm{Pb}$ were observed at all locations.

The correlation coefficients between the concentrations of the same metal in seawater and brown algae are listed in Table 4. No significant correlation was recorded. Metal concentrations in seawater showed wide fluctuations. Also, brown algae examined in the current study recorded different affinities toward metal uptake. The uptake of metals by algae from seawater behaves bimodal process, i.e., rapid adsorption and slow absorption (Benkdad et al. 2011).

On the other hand, the correlation coefficients between different metal concentrations in brown algae are presented in Table 5. Positive significant correlations were recorded between $\mathrm{Cr}-\mathrm{Cu}, \mathrm{Cr}-\mathrm{Cd}$ and $\mathrm{Mn}-\mathrm{Cu}$. The coefficients of these correlations were above 0.5 at confidence levels of 0.05 , which reflects significant variations in metal uptake by brown algae species.

For a compartive study, Table 6 shows the ranges of metal concentrations in brown algae from the Sudanese Red Sea coast and other areas in the world. Cr concentrations in the Sudanese Red Sea coast were found higher than those in other areas in the world. The levels of $\mathrm{Zn}, \mathrm{Cd}$

Table 4 Correlation coefficients between the same metal concentrations in seawater and brown algae

\begin{tabular}{llllllll}
\hline Metal & $\mathrm{Cr}$ & $\mathrm{Mn}$ & $\mathrm{Ni}$ & $\mathrm{Cu}$ & $\mathrm{Zn}$ & $\mathrm{Cd}$ \\
\hline Correlation coefficient & 0.256 & 0.140 & 0.155 & -0.055 & 0.084 & 0.264 & 0.407 \\
Significant (2-tailed) & 0.299 & 0.814 & 0.195 & 0.819 & 0.799 & 0.345 & 0.077 \\
\hline
\end{tabular}

Table 5 Correlation coefficients between different metal concentrations in brown algae

\begin{tabular}{|c|c|c|c|c|c|c|c|}
\hline & $\mathrm{Cr}$ & $\mathrm{Mn}$ & $\mathrm{Ni}$ & $\mathrm{Cu}$ & $\mathrm{Zn}$ & $\mathrm{Cd}$ & $\mathrm{Pb}$ \\
\hline $\mathrm{Cr}$ & 1.000 & & & & & & \\
\hline $\mathrm{Mn}$ & 0.409 & 1.000 & & & & & \\
\hline $\mathrm{Ni}$ & 0.023 & 0.413 & 1.000 & & & & \\
\hline $\mathrm{Cu}$ & $0.650^{\mathrm{a}}$ & 0.690 & 0.433 & 1.000 & & & \\
\hline $\mathrm{Zn}$ & 0.282 & 0.053 & 0.292 & 0.497 & 1.000 & & \\
\hline $\mathrm{Cd}$ & $0.810^{\mathrm{b}}$ & 0.237 & -0.226 & $0.435^{\mathrm{a}}$ & 0.027 & 1.000 & \\
\hline $\mathrm{Pb}$ & 0.299 & 0.453 & 0.313 & 0.287 & 0.361 & 0.146 & 1.000 \\
\hline
\end{tabular}


Table 6 Metal concentrations ( $\mu \mathrm{g} / \mathrm{g}$, dry wt.) in brown algae from the Sudanese Red Sea coast and other areas in the world

\begin{tabular}{|c|c|c|c|c|c|c|c|c|c|}
\hline Area & Species & $\mathrm{Cr}$ & $\mathrm{Mn}$ & $\mathrm{Ni}$ & $\mathrm{Cu}$ & $\mathrm{Zn}$ & $\mathrm{Cd}$ & $\mathrm{Pb}$ & References \\
\hline $\begin{array}{l}\text { Sudanese } \\
\text { Red Sea } \\
\text { coast }\end{array}$ & $\begin{array}{l}\text { Turbinaria, Sargassum, } \\
\text { Cystoseira, Padina } \\
\text { and Cystoseira }\end{array}$ & $4.95-16.95$ & $2.93-257.32$ & $1.35-7.43$ & $0.83-14.10$ & $4.13-19.13$ & $0.03-0.15$ & $0.45-2.18$ & Current study \\
\hline $\begin{array}{l}\text { Saudi } \\
\text { Arabian } \\
\text { Gulf } \\
\text { coast }\end{array}$ & $\begin{array}{l}\text { P. gymnospora, } C . \\
\text { myrica, } H . \text { triquetra } \\
\text { and S. angustifolium }\end{array}$ & $\mathrm{NR}^{\mathrm{a}}$ & $\mathrm{NR}^{\mathrm{a}}$ & $\mathrm{NR}^{\mathrm{a}}$ & $3.95-11.23$ & $\begin{array}{r}15.70- \\
75.25\end{array}$ & $0.64-1.95$ & $8.84-18.84$ & $\begin{array}{l}\text { Al-Homaidan } \\
\text { (2006) }\end{array}$ \\
\hline $\begin{array}{l}\text { Kutch } \\
\text { Gulf, } \\
\text { India }\end{array}$ & Padina & $2.0-2.3$ & $20.30-26.70$ & $0.60-3.8$ & $3.3-3.7$ & $29.0-282.0$ & $6.4-8.2$ & $0.28-1.80$ & $\begin{array}{l}\text { Chakraborty } \\
\text { et al. } \\
(2014)\end{array}$ \\
\hline $\begin{array}{c}\text { Rabta Bay, } \\
\text { Algeria }\end{array}$ & Dictyota & $0.89-0.91$ & $\mathrm{NR}^{\mathrm{a}}$ & $\mathrm{NR}^{\mathrm{a}}$ & $2.84-3.14$ & $4.93-5.23$ & $0.098-0.133$ & $0.94-1.48$ & $\begin{array}{l}\text { Laib and } \\
\text { Leghouchi } \\
\text { (2012) }\end{array}$ \\
\hline $\begin{array}{r}\text { Black Sea, } \\
\text { Bulgaria }\end{array}$ & Cystoseira & $\mathrm{NR}^{\mathrm{a}}$ & $\mathrm{NR}^{\mathrm{a}}$ & $\mathrm{NR}^{\mathrm{a}}$ & $\mathrm{NR}^{\mathrm{a}}$ & $\mathrm{NR}^{\mathrm{a}}$ & $0.13-0.20$ & $0.56-1.47$ & $\begin{array}{l}\text { Manev et al. } \\
\text { (2013) }\end{array}$ \\
\hline
\end{tabular}

${ }^{\text {a }}$ Not reported

and $\mathrm{Pb}$ in brown algae from the Arabian Gulf (Al-Homaidan 2006) were higher than those from the Sudanese Red Sea coast. High levels in the Arabian Gulf could be attributed to more manmade activities, in particular oil industry, than in the Red Sea. Subsequent studies in the Arabian Gulf showed a trend of increasing of metal concentrations (Naser 2013). Mn and Cu concentrations, which were recorded in some previous studies (Chakraborty et al. 2014; Laib and Leghouchi 2012), were within the ranges those found in the current study. The Kutch Gulf, India (Chakraborty et al. 2014) recorded higher levels of $\mathrm{Zn}, \mathrm{Cd}$ and $\mathrm{Pb}$ than those reported in the current study as well as the Rabta Bay (Laib and Leghouchi 2012) and the Black Sea (Manev et al. 2013).

\section{Conclusions}

The uptake of heavy metals by brown algae at the Sudanese Red Sea coast was examined. Metal uptake was in the following descending order: $\mathrm{Mn}>>\mathrm{Zn} \approx \mathrm{Cr}>\mathrm{Cu} \approx-$ $\mathrm{Ni}>\mathrm{Pb}>\mathrm{Cd}$. Different affinities of brown algae species toward metal uptake were recorded. Padina sp. and Cystoseira sp. recorded higher metal uptake than Turbinaria sp. and Sargassum sp. Accordingly, Padina sp. and Cystoseira sp. are recommended to be used for metal uptake examination. On the other hand, brown algae from Haloot location recorded the highest uptake of $\mathrm{Cr}, \mathrm{Mn}, \mathrm{Cu}, \mathrm{Zn}$ and $\mathrm{Cd}$, which may indicate possible contamination. High $\mathrm{Mn}$ uptake was also recorded in algae from Klaineb and Haidob locations. Additionally, elevated $\mathrm{Zn}$ contents in algae from Flamingo, Abuhashish and Sawakin locations were observed.
Open Access This article is distributed under the terms of the Creative Commons Attribution 4.0 International License (http:// creativecommons.org/licenses/by/4.0/), which permits unrestricted use, distribution, and reproduction in any medium, provided you give appropriate credit to the original author(s) and the source, provide a link to the Creative Commons license, and indicate if changes were made.

\section{References}

Al-Homaidan AA (2006) Brown Algae as biomonitors of heavy metal pollution along the Saudi Coast of the Arabian Gulf. Saudi J Biol Sci 13:99-103

Benkdad A, Laissaoui A, Tornero MV, Benmansour M, Chakir E, Garrido IM, Moreno JB (2011) Trace metals and radionuclides in macroalgae from Moroccan coastal waters. Environ Monit Assess 182:317-324

Cazón JP, Viera M, Donati E, Guibal E (2013) Zinc and cadmium removal by biosorption on Undaria Pinnatifida in batch and continuous processes. J Environ Manage 129:423-434

Chakraborty S, Bhattacharya T, Singh G, Maity JP (2014) Benthic macroalgae as biological indicators of heavy metal pollution in the marine environments: a biomonitoring approach for pollution assessment. Ecotoxicol Environ Safe 100:61-68

Davis TA, Volesky B, Mucci A (2003) A review of the biochemistry of heavy metal biosorption by brown algae. Water Res 37:4311-4330

Duan D, Ran Y, Cheng H, Chen J, Wan G (2014) Contamination trends of trace metals and coupling with algal productivity in sediment cores in Pearl River Delta, South China. Chemosphere 103:35-43

Försberg A, Söderlung S, Frand A, Petersson LR, Pedresén M (1988) Studies on metal content in the brown seaweed, Fucus Vesiculosus, from the archipelago of Stockholm. Environ Pollut 49:245-263

Hashim MA, Chu KH (2004) Biosorption of cadmium by brown, green, and red seaweeds. Chem Eng J 97(2-3):249-255

Idris AM (2008) Combining multivariate statistical analysis and geochemical approaches for the assessment of the level of heavy 
metals in sediments from Sudanese harbors along the Red Sea coast. Microchem J 90:159-163

Idris AM, El-Tayeb MAH, Potgieter-Vermaak SS, Grieken RV, Potgieter JH (2007) Assessment of heavy metals pollution in sediments harbours along the Red Sea coast. Microchem J 87:104-112

Jordanova AV, Strezov AS, Ayranov MI, Stoilova TT (1999) Heavy metal assessment in algae, sediments and water from the Bulgarian Black Sea coast. Water Sci Technol 39(8):207-212

Khristoforova NK, Kozhenkova SI (2002) The use of the brown algae Sargassum Spp. in heavy metal monitoring of the marine environment near Vladivostok, Russia. Ocean Polar Res 24:325-329

Laib E, Leghouchi E (2012) Cd, Cr, Cu, Pb, and Zn concentrations in Ulva lactuca, Codium fragile, Jania rubens, and Dictyota dichotoma from Rabta Bay, Jijel (Algeria). Environ Monit Assess 184:1711-1718

Lee S-H, Park C-H (2012) Biosorption of heavy metal ions by brown seaweeds from southern coast of Korea. Biotechnol Bioprocess Eng 17:853-861

Manev Z, Iliev A, Vachkova V (2013) Chemical characterization of brown seaweed-Cystoseira barbata. Bulg J Agric Sci 19(Suppl. 1):12-15
Montazer-Rahmati MM, Rabbani P, Abdolali A, Keshtkar AR (2011) Kinetics and equilibrium studies on biosorption of cadmium, lead, and nickel ions from aqueous solutions by intact and chemically modified brown algae. J Hazard Mater 185:401-407

Morrison L, Baumann HA, Stengel DB (2008) An assessment of metal contamination along the Irish coast using the seaweed Ascophyllum nodosum (Fucales, Phaeophyceae). Environ Pollut 152:293-303

Naser HA (2013) Assessment and management of heavy metal pollution in the marine environment of the Arabian Gulf: a review. Mar Pollut Bull 72:6-13

Phillips DJH (1990) Use of macroalgae and invertebrates as monitors of metal levels in estuaries and coastal waters. In: Furness RW, Rainbow PS (eds) Heavy metals in the marine environment. CRC Press, Boca Raton, pp 81-99

Rajfur M, Klos A, Waclawek M (2010) Sorption properties of algae Spirogyra sp. and their use for determination of heavy metal ions concentrations in surface water. Bioelectrochemistry 80:81-86

Strezov A, Nonova T (2003) Monitoring of $\mathrm{Fe}, \mathrm{Mn}, \mathrm{Cu}, \mathrm{Pb}$ and $\mathrm{Cd}$ levels in two brown macroalgae from the Bulgarian Black Sea coast. Intern J Environ Anal Chem 83:1045-1054 